\title{
Podręczniki i książki dla nauczycieli, dzieci i młodzieży w ofercie wydawniczej oficyny Friedleinów w Krakowie
}

Na przełomie XVIII i XIX w. ruch wydawniczy w Krakowie został zdominowany przez drukarzy niemieckich, a zwłaszcza przez Józefa Trasslera, który wydawał podręczniki, pisma urzędowe, kalendarze i gazetę „Krakauer Zeitung” (do 1808 r.). W języku polskim wychodziła wówczas jedynie "Gazeta Krakowska1. W końcu XVIII w. do Krakowa wyemigrowało wiele rodzin wielce zasłużonych dla drukarstwa i księgarstwa. Przybywali oni do królewskiego miasta głównie z Czech, Moraw, Śląska oraz Austrii. Wśród nich można wymienić np. rodziny: Greblów, Helzlów, Klugerów, Kochów, Koffów, Kremerów, Modesów, Morbitzerów, Walterów czy Wolfów. Do tych rodzin zaliczała się również familia Friedleinów².

Friedleinowie byli rodziną, która wywodziła się z bawarskiego miasteczka Deutenheim, leżącego nieopodal Würzburga, w pobliżu Neustadt nad rzeką Aisch. W tym miasteczku mieszkał pastor Karol Fryderyk Friedlein z żoną Elżbietą Rebeką Sybillą z domu Steinhauserin. Małżeństwo to miało dziewięcioro dzieci, które rozjechały się po świecie. Najmłodszy z Friedleinów przywędrował aż do Krakowa. Według rodzinnej legendy, Friedleinowie nie byli z pochodzenia Niemcami, ale wywodzili się z Włoch, skąd w XVIII w. do Bawarii przywędrował rzemieślnik o nazwisku Pacelli, który tam się osiedlił i zmienił nazwisko na Friedlein ${ }^{3}$.

W Krakowie rodzina Friedleinów osiadła pod koniec XVIII stulecia, a w historii królewskiego miasta kojarzona była przede wszystkim z księgarstwem, którym członkowie rodziny zajmowali się od pokoleń. Żródła wskazują, iż Friedleinowie

* Doktorant, Uniwersytet im. Jana Kochanowskiego w Kielcach.

1 J. M. Małecki, Pod rządami austriackimi i w Księstwie Warszawskim (1796-1815), [w:] J. Bieniarzówna, J. M. Małecki, Dzieje Krakowa, t. 3: Kraków w latach 1796-1918, Kraków 1979, s. 17-18.

2 E. Chełstowski, Katalogi księgarskie Friedleinów, „Księgarz” 1960, nr 1/2, s. 19.

3 J. Adamczewski, Mała encyklopedia Krakowa, Kraków 1997, s. 132; tenże, Krakowskie rody, Kraków 1994, s. 273; List Józefa Friedleina do Kazimierza Władysława Wójcickiego, oprac. M. Buczak, „Rocznik Biblioteki PAN w Krakowie” 1970, T. 16, s. 141. 
byli również wydawcami, a do nich należeli: Jan Jerzy Fryderyk i jego synowie Fryderyk, Daniel Edward, Rudolf Fryderyk oraz Józef Edward (syn Daniela Edwarda) i jego wnukowie Józef i Edward Münnich ${ }^{4}$.

Jan Jerzy Fryderyk (1771-1834), uznany za nestora krakowskiego rodu Friedleinów, przybył do Krakowa w 1796 r. jako „wędrowny towarzysz introligatorski”. Początkowo jednak musiał zdobyć potrzebne w zawodzie doświadczenie, które zyskał pracując w warsztacie Marcina Pietrzykowskiego. W roku 1797 młody Friedlein nabył kamienicę w Rynku Głównym, gdzie założył zakład introligatorski, a następnie czytelnię publiczną (o którą zabiegał od roku 1798). Niestety, później zmuszony został do jej zamknięcia ze względu na zakaz wydany przez Austriaków, który dotyczył prowadzenia czytelni, a przede wszystkim obecności w niej polskich książek ${ }^{5}$.

W kolejnych latach jego kariera jako introligatora przybrała większe tempo - w latach 1797-1802 Jan Jerzy Fryderyk został podstarszym cechu, a później kilka razy wybierany był starszym cechu6. Wraz z opuszczeniem Krakowa przez Austriaków Friedlein ponownie otworzył swoją czytelnię ok. 1810 r. w Rynku Głównym pod numerem 13, zaś pięć lat później wydał pierwszy katalog swojej wypożyczalni i czytelni w języku niemieckim (kolejny ukazał się w 1821 r. $)^{7}$. Założyciel krakowskiego rodu Friedleinów w 1809 r. wykupił od Józefa Jerzego Trasslera - wiedeńczyka, wydawcy „Krakauer Zeitung”, jego warsztat introligatorski i skład książek, który znajdował się w tzw. Domu Hetmańskim - później nazywanym Kamienicą Hetmańską 8 .

W 1828 r. Jan Jerzy Fryderyk Friedlein jeszcze za życia przekazał księgarnię i wypożyczalnię książek 26-letniemu wówczas synowi Danielowi Edwardowi (1802-1855) ${ }^{9}$, zachowując główną tradycję rodu Friedleinów - przekazywania dorobku zawodowego pierworodnemu synowi. Następnie w 1830 r. nowy właściciel firmy wykupił cały zasób książek, które pochodziły ze zlikwidowanej księgarni Jacka Bartłomieja Drelinkiewicza, co okazało się ważnym krokiem dla rozwoju jego działalności księgarskiej i antykwarycznej, ponieważ stworzyło solidne podstawy do sukcesywnego powiększania księgozbioru w późniejszych latach działalności księgarskiej i antykwarycznej. Ponadto w 1831 r. Daniel Edward Friedlein wystąpił z prośbą o pozwolenie na prowadzenie drukarni. Natomiast w 1832 r. powiększył swoją firmę, wykupując zasób książkowy z księgarni Jana Maja, a po śmierci ojca połączył obie marki w jedną i umieścił księgarnię oraz swoją wypożyczalnię książek w Rynku Głównym¹0.

${ }_{4}$ Wielka encyklopedia powszechna PWN, T. 4, kom. red. B. Suchodolski, Warszawa 1962, s. 28; Ł. Romaniuk, Działalność wydawnicza, księgarska i introligatorska Friedleinów w Krakowie oraz Warszawie w latach 1796-1956 (w druku).

5 J. Adamczewski, Mała encyklopedia..., s. 132; Encyklopedia wiedzy o książce, red. A. Birkenmajer i in., Wrocław-Warszawa-Kraków 1971, s. 759-760.

6 J. Adamczewski, Mała encyklopedia..., s. 132; J. Pachoński, Zmierzch sławetnych. Z życia mieszczan w Krakowie w XVII i XVIII wieku, Kraków 1956, s. 170.

7 Słownik pracowników książki polskiej, red. I. Treichel, Warszawa-Łódź 1972, s. 233.

8 A. Pietruczak, Ciąg dalszy wspaniałej historii, „Wiadomości Księgarskie” 2006, nr 3, s. 52.

9 J. Adamczewski, Krakowskie..., s. 276.

10 Słownik pracowników..., s. 233. 
Syn Jana Jerzego Fryderyka znacznie rozwinął ojcowską firmę, koncentrując się nie tylko na nowościach wydawniczych, ale również na sprzedaży dzieł antykwarycznych, nakładów własnych i zagranicznych, rycin, monet, medali oraz dzieł sztuki. Daniel Edward Friedlein zasłynął w tamtych czasach umiejętnością omijania cenzury - sprowadzał z zagranicy, przede wszystkim w czasie Wiosny Ludów, różne druki emigracyjne, przemycał czasopisma, które później udostępniał chętnym $w$ formie prenumeraty ${ }^{11}$. Ponadto $w$ Krakowie uważany był również za tego, który na szerszą skalę upowszechnił literaturę dla najmłodszych odbiorców $^{12}$. Daniel Edward Friedlein własnym nakładem wydał ok. 50 tytułów, wśród których znajdują się prace naukowe, dzieła religijne i literackie, podręczniki, słowniki, albumy oraz atlasy ${ }^{13}$.

Tradycje rodu Friedleinów - księgarzy, drukarzy, wydawców i introligatorów, kontynuował pierworodny syn Daniela Edwarda - Edward Józef Friedlein, późniejszy prezydent miasta Krakowa (1831-1917) $)^{14}$. Józef Friedlein kontynuował działalność firmy w zapoczątkowanych przez ojca formach, zachował ponadto nazwę przedsiębiorstwa „D. E. Friedlein”. Podobnie jak ojciec prowadził handel komisowy wydawnictwami Krakowskiego Towarzystwa Naukowego, a od 1878 r. prowadził wyłączną sprzedaż wydawnictw Akademii Umiejętności. Wiadomo również, że był dostawcą książek dla Biblioteki Szkoły Handlowej w Warszawie. Do swojego komisu przyjmował różnorodne książki, a jego działania w tej dziedzinie budziły podziw i uznanie - Józef Friedlein posiadał bowiem wyjątkową umiejętność znajdowania dzieł rzadkich i publikacji już wyczerpanych ${ }^{15}$.

Trudno przecenić rolę, jaką księgarnia D. E. Friedleina pełniła w Krakowie. Ponad wszelką wątpliwość za czasów Józefa Friedleina była nie tylko dobrze prosperującym przedsiębiorstwem, ale również miejscem, w którym stawiano na kwestie narodowe i patriotyczne. Zatem jej funkcjonowanie miało szczególne znaczenie w życiu Krakowa i jego mieszkańców ${ }^{16}$. Ponadto Józef Friedlein rozwinął i prowadził handel antykwaryczny, jak również gromadził ryciny, mapy oraz numizmaty. Poprzez wydanie dużej liczby katalogów dbał o właściwe opracowanie i promocję zbiorów oraz, podobnie jak jego poprzednicy, wydawał dzieła naukowe, literaturę, podręczniki szkolne, albumy, mapy oraz nuty ${ }^{17}$.

Po Józefie Edwardzie tradycje rodu Friedleinów przejęła córka Emilia wraz z mężem Leopoldem Münnichem. Na początku małżonkowie Münnich sami zajmowali się księgarnią i wydawnictwem, ale z czasem przekazali je swoim synom - Józefowi i Edwardowi ${ }^{18}$.

Specjalnością Józefa Münnicha (1880-1939) było opracowywanie i wydawanie katalogów, którego przykładem jest chociażby Katalog książek dla dzieci

11 Ł. Romaniuk, Działalność..., s. 80.

12 A. Aleksiewicz, Drukarstwo w Rzeczypospolitej Krakowskiej i Galicji zachodniej w latach 1815-1860, Warszawa-Wrocław 1976, s. 103.

${ }_{13}$ Encyklopedia Krakowa, red. D. Kalisiewicz, Warszawa-Kraków 2000, s. 218.

14 Tamże.

15 Encyklopedia wiedzy..., s. 761.

16 Ł. Romaniuk, Działalność..., s. 98.

17 Encyklopedia Krakowa..., s. 218.

18 J. Adamczewski, Krakowskie..., s. 283-293. 
i młodzieży oraz dzieł na podarki dla osób starszych zestawiony ze wszystkich w tym obecnie istniejących wydawnictw przez Józefa Münnicha (Kraków 1902 r.). Katalog ten został wydany pod nazwą firmy Friedleina. Następne katalogi Józef Münnich wydał już pod własną firmą (podpisując je swoimi inicjałami J. M.) $)^{19}$. Do 1917 r. nakładem firmy ukazało się kilka pozycji z zakresu literatury pięknej oraz publikacje dla młodzieży. Dbano, żeby zawsze były w starannej szacie graficznej. Ponadto zaczęto wydawać książki seryjne, np. w ramach „Biblioteki Podręcznej Friedleina” (tomy 1-6). Redaktorem serii był Wilhelm Feldman ${ }^{20}$. Dodatkowo nakładem księgarni opublikowane zostały wydania szkolne pisarzy greckich i rzymskich (około 40 pozycji), które były zatwierdzone do użytku w galicyjskich gimnazjach. Z początkiem 1917 r. przekształcono firmę w Spółkę z ograniczoną odpowiedzialnością, której udziałowcami zostali bracia Józef i Edward Münnichowie oraz Józef Friedlein (po śmierci dziadka - sami bracia). W tym czasie Józef Münnich rozwinął działalność antykwaryczną. W roku 1923 prowadzenie rodzinnej firmy zostawił bratu, a sam z częścią zbiorów przeniósł się do Poznania, gdzie w dzielnicy Jeżyce, przy ulicy Kraszewskiego 17, założył antykwariat pod nazwą „Wiedza”. W 1927 r. zlikwidował poznańską firmę i powrócił do Krakowa, tu osiadł przy ulicy Brackiej. W 1931 r. ponownie przeniósł swój antykwariat do lokalu księgarni D. E. Friedleina, wydając przy tym 17 kolejnych katalogów. Od lutego 1936 r. objął całe kierownictwo firmy (po tym, jak brat Edward wystąpił ze spółki) i prowadził ją aż do śmierci, czyli do 1939 r. $^{21}$

Drugi z braci, Edward Münnich (1882-1965), po śmierci dziadka - Józefa Friedleina, przejął kierownictwo nad rodzinnym interesem i prowadził je do początków 1936 r. W czasie wojny w 1942 r. został przez hitlerowców wysiedlony z lokalu w Rynku Głównym 17 i przeniesiony do małego pomieszczenia na peryferie Krakowa (Rynek Podgórski 8). Tam prowadził główny antykwariat i skład materiałów piśmienniczych. Jednakże w czasie przymusowej przeprowadzki część zasobów antykwariatu, księgarni i składu nut uległa zniszczeniu. Po zakończeniu wojny Edward podjął próbę wznowienia działalności wydawniczej, publikując kilka książek obrazkowych dla dzieci, a także z okazji 150-lecia działalności firmy (1946 r.) wznowił Historię Polski Lucjana Rydla. W roku 1955 sprzedał Bibliotece Ossolineum we Wrocławiu zbiór korespondencji księgarni Friedleinów (1830-1903) i osobistą korespondencję Józefa Friedleina (18811904). Dnia 30 kwietnia 1956 r. Edward Münnich postanowił zakończyć działalność i zlikwidował księgarnię ${ }^{22}$. Na tym kończy się tak wspaniała historia tej jakże zasłużonej dla dziejów krakowskiej książki rodziny: wydawców, księgarzy, drukarzy, introligatorów i bibliofilów.

O działalności wydawniczej oraz księgarskiej rodziny Friedleinów w Krakowie możemy dowiedzieć się z katalogów firmy, które były wydawane przez nich

19 E. Chełstowski, Katalogi księgarskie..., s. 20.

20 Wilhelm Feldman (1868-1919), publicysta, prozaik i dramatopisarz, krytyk oraz historyk literatury. Autor m.in. Współczesnej literatury polskiej.

21 Słownik pracowników..., s. 614; J. Adamczewski, Krakowskie..., s. 293.

22 Słownik pracowników..., s. 614-615; J. Adamczewski, Krakowskie..., s. 293. 
samych. Prekursorem i twórcą spisów oraz katalogów w księgarni D. E. Friedleina był Daniel Edward.

W oficynie wydawniczej, księgarni oraz antykwariacie Friedleinów reprezentowane były różne rodzaje katalogów, wśród których można wymienić katalogi nakładowe, sortymentowe, komisowe i typu mieszanego. Ponadto publikowano katalogi specjalne, w których można było znaleźć zestawienie piśmiennictwa na określony temat. Wydano też katalogi obejmujące określony typ dokumentów, np. podręczniki oraz katalogi antykwaryczne (monet i medali, map, rycin), czy katalogi adresowane do określonego czytelnika, np. dla młodzieży ${ }^{23}$.

Jak wynika z ustaleń Anny Grucy, „Katalogi księgarskie stanowią cenne źródło $\mathrm{w}$ badaniach nad działalnością konkretnej firmy wydawniczo-księgarskiej. Czerpiemy z nich wówczas informacje o ofercie wydawniczej (książki, nuty, ryciny) badanej księgarni. [...]. Katalogi [zawieraja] też zapowiedzi wydawnicze. Informacje o pojedynczych tytułach będących w druku, albo o zamiarze wydania serii, cykli, czy czasopism"24.

Przykładem takiego katalogu u Friedleinów może być Katalog książek polskich czytelni D. E. Friedleina księgarza z roku 1844, w którym to Daniel Edward Friedlein zamieścił spis książek religijnych wydany swoim nakładem. Wśród kilku pozycji przeznaczonych dla dorosłych w tym spisie znajduje się również Zbiór modlitw dla dzieci przeznaczony dla młodszych czytelników. Ponadto komunikował w nim, że jego księgarnia posiada na składzie i oferuje „szanownej publiczności” dzieła polskich twórców, nuty, ryciny, litografię oraz odlewy gipsowe ${ }^{25}$.

Analizując dostępne katalogi księgarskie rodziny Friedleinów, należy w nich wyodrębnić literaturę dziecięcą, którą jako pierwszy na szerszą skalę upowszechnił Daniel Edward Friedlein, a po nim jego następcy. Wśród tej literatury można wyróżnić książki elementarne dla szkół początkowych, które były bardzo wartościowe, a zarazem rzadko wychodziły spod pras drukarskich. Drukarnia D. E. Friedleina wydała m.in. takie tytuły, jak: $A B C$ dla dobrych dzieci, abecadło w rozmaitych kolorach (1837); Abecadło ruchome dla dzieci poczynających poznawać zgłoski (1840); Abecadło polskie z kwiateczkami dla dzieci lubiących takowe pielęgnować (1840) Antoniny Jachowiczowej ${ }^{26}$; Prawidła pisania (1841) Karola Mecherzyńskiego, która to pozycja służyła jako podręcznik do nauki pisania i poznawania zasad pisowni.

Ponadto spod pras Friedleinów wyszły książki dla młodzieży uczącej się, wśród których można wyróżnić: Historię języka łacińskiego w Polsce (1833) Karola Mecherzyńskiego; Dzieje narodu polskiego dla użytku młodzieży szkolnej

${ }^{23}$ A. Gruca, Krakowskie katalogi księgarskie doby autonomii galicyjskiej. Typologia $i$ wartość źródłowa w kontekście przemian form informacji o dawnej książce, [w:] Uniwersum piśmiennictwa wobec komunikacji elektronicznej, red. K. Migoń, M. Skalska-Zlat, Wrocław 2009, s. 66-67.

${ }^{24}$ A. Gruca, Katalog księgarski jako źródło informacji o książce i rynku wydawniczo-księgarskim oraz druk reklamowy (na przykładzie katalogów krakowskich z drugiej połowy XIX wieku), [w:] Książka, biblioteka, informacja. Między podziałami a wspólnotą, red. J. Dzieniakowska, M. Olczak-Kardas, Kielce 2012, s. 82; zob. też G. Piechota, A. Kida, Rozwój reklamy i promocji książek edukacyjnych w Katalogach księgarskich od XVIII wieku do współczesności, tamże, s. 241-257.

${ }_{25}$ Szerzej: Katalog książek polskich czytelni D. E. Friedleina księgarza, Kraków 1844, s. [nlb].

${ }^{26}$ A. Aleksiewicz, Drukarstwo... s. 103. 
ułożone przez Lucjana Siemieńskiego; Wśród dziejowej zawieruchy: obrazy historyczne od 1758-1796 r.[oku] (1903) oraz Z Orląt Orły. Powiastki i obrazy historyczne dla młodzieży (1906) napisane przez Mieczysławę Śleczkowską, które to pozycje były pomocne przy nauce historii dla młodzieży. Ponadto Podręcznik do dziejów literatury polskiej (1901) ułożony przez Antoniego i Mikołaja Mazanowskich i Dzieje literatury powszechnej; podręcznik do nauki szkolnej (1903) ułożony przez Wiktora Doleżana, a przeznaczone do nauki literatury.

Oprócz książek mających uczyć, w oficynie drukowano książki mające na celu bawić i wychowywać dzieci. Takim przykładem mogą być książki Klementyny z Tańskich Hoffmanowej Wiązanie Helenki (1839), Druga książeczka Helenki (1839), Olesia i Adaś (1844) oraz Assarmot zabawa historyczna (1850), która to książka służyła również jako gra planszowa do edukacji historycznej, czy publikacja Julii Darowskiej Nagroda dla pilnych dzieci (1837) ${ }^{27}$.

Natomiast do literatury młodzieżowej zaliczały się Madejowe łoże: stara klechda dla młodych czytelników w XX pieśniach (1909) Lucjana Rydla, Przy kominku: opowieści fantastyczne dla młodzieży (1911) Antoniny Domańskiej, czy Straszne przygody kropelki wody (1943) Izy Ostrowskiej.

Ponadto oficyna Friedleinów tłoczyła również podręczniki i książki pomocne w pracy nauczycielom. Były to m.in. następujące tytuły: Pedagogika do użytku seminariów nauczycielskich i nauczycieli szkół ludowych (1902) Mieczysława Baranowskiego; Młoda Polska w powieści, liryce i dramacie (1902) Antoniego Mazanowskiego; podręcznik Zarys dziejów literatury polskiej na podstawie badań najnowszych pracowników [!] dla użytku szkolnego i podręcznego (1869) nakreślony przez Adama Kuliczkowskiego; podręcznik do psychologii wychowawczej Ze studiów nad nauczaniem psychologii w szkołach średnich (1911) Karola Bobrzyńskiego oraz Uwagi nad kwestią językową w szkołach i uniwersytetach Galicji i Krakowa osnowane na liście odręcznym jego C. K. Apostolskiej Mości z dnia 20 października 1860 r. (1860) Antoniego Zygmunta Helcela.

Warto w tym miejscu wspomnieć, że Daniel Edward Friedlein był jednym z pierwszych, który wydał katalog, a w zasadzie wykaz podręczników dostępnych w swojej księgarni, z myślą i na potrzeby szkół. Był to Wykaz ilości i ceny książek na trzy klasy wydziałowe przez Kollegium Nauczycielskie tej szkoły do używania obranych r. 1834/35, które dostać można w księgarni D. E. Friedleina, który zachował się w zbiorach Biblioteki Jagiellońskiej. Katalog ten został wydany w 1834 r. W omawianym wykazie zamieszczono podręczniki dla klas I-III. Dodatkowo wykaz podręczników wzbogacony został o Spis książek szkolnych przeznaczonych do Liceum św. Anny i św. Barbary, który można dostać w księgarni $D$. E. Friedleina. Spis ten zawierał książki do nauki języków obcych (niemieckiego i francuskiego) dla początkujących i postępujących w nauce oraz podręczniki dla uczniów klas I-VI, które były używane w Liceum św. Anny i św. Barbary ${ }^{28}$.

27 Tamże.

${ }^{28}$ E. Chełstowski, Katalogi księgarskie..., s. 19; Szerzej: Wykaz ilości i ceny książek na trzy klasy wydziałowe przez Kollegium Nauczycielskie tej szkoły do używania obranych r. 1834/35, które dostać można w księgarni D. E. Friedleina w tym spis książek szkolnych przeznaczonych do liceum 
Ponadto duży wkład Daniel Edward Friedlein włożył w wydrukowanie podręcznych słowników językowych, gdyż robił to na własny koszt, po bardzo przystępnych cenach. Dzięki jego zaangażowaniu zostały wydane następujące pozycje: Słownik podręczny polsko-niemiecki (1839); Słownik podręczny niemiecko-polski (1842) w opracowaniu Jana Bętkowskiego oraz Słownik podręczny francusko-polski (1840) pod redakcją Aleksandra Cukrewicza w wydaniu normalnym i tańszym. Następnie wydał również słowniki fachowe autorstwa Józefa Majera i Ferdynanda Skobla Niemiecko-polski słownik wyrazów lekarskich (1842); Objaśnienia spostrzeżeń nad wyrazami lekarskimi (1835) ${ }^{29}$; Objaśnienia spostrzeżeń nad wyrazami lekarskimi umieszczonych w tomie trzecim Kwartalnika Naukowego (1836). Ponadto nakładem drukarni wyszedł Słownik heraldyczny do pomocy w poszukiwaniach, m.in. archeologicznych, ułożony przez Stanisława Krzyżanowskiego.

Warto również nadmienić, że firma D. E. Friedleina wydawała książki z różnych dziedzin nauki, takich jak filologia, np. czterotomowe Pomniki historii literatury polskiej (1835) Michała Wiszniewskiego czy Prelekcje o filologii klasycznej $i$ jej encyklopedii (1850). Ponadto w bogato reprezentowanym repertuarze z zakresu literatury naukowej w oficynie Friedleinów wydrukowano również dzieła z takich dziedzin, jak: medycyna, farmacja, przyroda, historia, prawo, fizyka oraz filozofia. Należały do nich takie tytuły, jak: Krótka wiadomość o kąpielach słonych w Wieliczce (1837) napisana przez Feliksa Boczkowskiego - doktora medycyny; O pojęciu choroby ze stanowiska filozofii (1837) Fryderyka Skobla - profesora Uniwersytetu Jagiellońskiego; dotyczący nauki o zwierzętach Atlas zoologiczny w 45 tablicach z nazwami w języku polskim, niemieckim i łacińskim (1852), czy Opisanie najużywańszych roślin lekarskich pod względem ich podobieństwa i różnic z rycinami (1850) autorstwa Floriana Sawiczewskiego.

Istotną pozycję w wydawanym przez Friedleinów asortymencie stanowiła publikacja seryjna pod tytułem „Biblioteka Podręczników Friedleina” (numery 1-6). Seria ta została umieszczona przez Józefa Münnicha w wydanym w roku 1908 katalogu noszącym tytuł Katalog wydawnictw tanich jako to: Biblioteki Dzieł Wyborowych, Książek dla Wszystkich, Biblioteki Mrówki, Biblioteki Powszechnej, Arcydzieł polskich i obcych pisarzy (Westa) i innych i znajdowała się w dziale o nazwie „D. E. Friedleina Biblioteka podręczników”. W skład tej serii weszły następujące tytuły: podręcznik do socjologii Socjologia - jej zadania, szkoły i najnowsze postępy Achille Loria (nr 1); podręcznik do nauki metod wychowania fizycznego Zasady wychowania fizycznego Eugeniusza Piaseckiego (nr 2); podręcznik do filozofii Wstęp do filozofii Stanisława Brzozowskiego (nr 3); podręcznik z zakresu ekonomii politycznej Historia ekonomii politycznej Johna Kelsa Ingrama (nr 4-5); podręcznik o malarstwie Rozwój malarstwa polskiego. Cz. 1. (Od baroku do Matejki) Mariana Olszewskiego (nr 6) ${ }^{30}$. Były to niestety jedyne podręczniki, które ukazały się w tej serii.

św. Anny i św. Barbary, które dostać można w księgarni D. E. Friedleina, Kraków 1834; Ł. Romaniuk, Działalność..., s. 109.

29 A. Aleksiewicz, Drukarstwo..., s. 102.

30 Słownik pracowników..., s. 614; Katalog wydawnictw..., s. 66. 
Podsumowując, należy stwierdzić, iż Friedleinowie - rodzina krakowskich drukarzy, wydawców, księgarzy oraz kolekcjonerów, wnieśli trwały wkład w życie kulturalne i umysłowe Krakowa. Prowadzona przez poszczególnych członków rodu księgarnia stanowiła niewątpliwie jeden z głównych ośrodków ówczesnego życia umysłowego miasta, a należące do nich warsztaty introligatorskie i często modernizowane drukarnie były wysoko cenione w branży wydawniczej. Friedleinowie należeli również do dynamicznych przedsiębiorców utrzymujących ożywione kontakty zagraniczne, które przyczyniały się do rozwoju i postępu w ówczesnym drukarstwie i księgarstwie.

Wydawane przez oficynę Friedleinów publikacje, m.in.: dzieła naukowe, literackie, religijne, albumy litograficzne, nuty, słowniki, a także będące przedmiotem niniejszego opracowania podręczniki, książki dla dzieci, młodzieży i nauczycieli, charakteryzowały się wysokim poziomem edytorskim i artystycznym.

Daniel Edward Friedlein uznany został za pierwszego członka tego rodu, który na szeroką skalę wprowadził do programu wydawniczego oficyny literaturę dla najmłodszych. Z kolei Józef Friedlein był dostawcą książek naukowych dla Biblioteki Szkoły Handlowej w Warszawie.

Friedleinowie dbali również o promocję tego rodzaju literatury poprzez wydawanie stosownych katalogów księgarskich przeznaczonych m.in. dla najmłodszych odbiorców, którego przykładem jest chociażby Katalog książek dla dzieci i młodzieży oraz dzieł na podarki dla osób starszych zestawiony ze wszystkich w tym obecnie istniejących wydawnictw przez Józefa Münnicha.

Wydawane przez firmę Friedleinów przekłady szkolne pisarzy greckich i rzymskich znalazły się natomiast w programach lektur w galicyjskich gimnazjach, a książki elementarne służące do nauki czytania i pisania w szkołach początkowych były niezwykle wartościowe, rzadko bowiem wydawały je inne działające wówczas oficyny.

Daniel Edward wydał ponadto katalogi podręczników szkolnych dla szkół powszechnych i gimnazjum oraz spisy książek do nauki języków obcych. Zasługującą na uwagę pozycją było również wydanie publikacji seryjnej „Biblioteka Podręczników Friedleina", w której znalazły się książki do nauki: socjologii, wychowania fizycznego, filozofii, ekonomii politycznej, a nawet podręcznik malarstwa.

Mając na uwadze powyższe dokonania, należy podkreślić duży wkład rodzinnej firmy Friedleinów w rozwój wydawnictw dla dzieci, młodzieży i nauczycieli, w tym również książek do zabawy i rozrywki oraz podręczników z różnych dziedzin wiedzy oraz ich promocję i rozpowszechnianie na terenie ówczesnej Galicji, jak również poza jej granicami. Wydając swoje tytuły, Friedleinowie starali się odzwierciedlać stan nauk pedagogicznych tego okresu i rozpowszechniać z ówczesnej literatury przedmiotu to, co najwartościowsze, przyczyniając się tym samym do podnoszenia poziomu nauczania we wszystkich typach szkół, odpowiedniego przygotowania nauczycieli do pracy pedagogicznej, a tym samym mieli wyraźny udział w podnoszeniu kultury intelektualnej młodego pokolenia, co z kolei spowodowało wysunięcie się Krakowa na wybitne miejsce w życiu umysłowym Galicji, a nawet pozbawionego własnej państwowości narodu. 